\title{
Tubeworm-associated permanent meiobenthic communities from two chemically different hydrothermal vent sites on the East Pacific Rise
}

\author{
Sabine Gollner ${ }^{1, *}$, Julia Zekely ${ }^{1}$, Breea Govenar ${ }^{2,5}$, Nadine Le Bris ${ }^{3}$, \\ Hans L. Nemeschkal ${ }^{4}$, Charles R. Fisher ${ }^{2}$, Monika Bright ${ }^{1}$ \\ ${ }^{1}$ Department of Marine Biology, University of Vienna, Althanstrasse 14, 1090 Vienna, Austria \\ ${ }^{2}$ Department of Biology, The Pennsylvania State University, 208 Mueller Laboratory, University Park, Pennsylvania 16802, USA \\ ${ }^{3}$ Department Environnement Profond, Ifremer, Centre de Brest, BP 70, 29280 Plouzané, France \\ ${ }^{4}$ Department of Theoretical Biology, University of Vienna, Althanstrasse 14, 1090 Vienna, Austria \\ ${ }^{5}$ Present address: Biology Department, Woods Hole Oceanographic Institution, MS \#33, Woods Hole, Massachusetts 02543, USA
}

\begin{abstract}
The permanent meiobenthic community associated with aggregations of the tubeworm Riftia pachyptila was characterized at 2 different hydrothermal vent sites, Tica and Riftia Field, on the East Pacific Rise near 9 ${ }^{\circ} 50^{\prime} \mathrm{N}$. The maximum effluent temperatures were similar at both sites, but the chemistry of the hydrothermal fluids differed between sites. The abundance of meiobenthos was very low in 5 out of 6 samples $\left(<61\right.$ ind. $\left.10 \mathrm{~cm}^{-2}\right)$ and was higher at Tica $\left(20\right.$ to 976 ind. $\left.10 \mathrm{~cm}^{-2}\right)$ than at Riftia Field ( $<1$ to 12 ind. $10 \mathrm{~cm}^{-2}$ ). Meiobenthos abundance was positively correlated with the volume of sediment within the tubeworm aggregations. Sediment consisted mainly of particulate organic material and contained only a few mineral grains. A total of 33 meiobenthic species (15 of them new to science) was identified, comprising nematodes, copepods, ostracods, tanaidaceans, and foraminiferans. The meiobenthic fauna contributed a third to the total species richness in the benthic community associated with these tubeworm aggregations. There were 19 meiobenthic species shared between the 2 sites. The majority of meiobenthic species were first-order primary consumers. The most abundant taxa were nematodes and copepods, and other taxa were rare at both sites. Nematodes numerically dominated the community at Tica, while no clear dominance of a higher taxon could be detected at Riftia Field. Species richness was similar at both sites, whereas Shannon-Wiener diversity index and Pielou's evenness index were higher at Riftia Field. Due to the differences in the relative abundance of some species and unique occurrence of others at each site, the meiobenthic communities from the 2 different sites had an average Bray-Curtis dissimilarity of almost $70 \%$.
\end{abstract}

KEY WORDS: Meiobenthos · Meiofauna - Hydrothermal vent - East Pacific Rise • Nematodes · Copepods $\cdot$ Community study $\cdot$ Riftia pachyptila

\section{INTRODUCTION}

Since the discovery of the Galápagos Spreading Center and the resident fauna in 1977, numerous hydrothermal vent sites have been explored around the globe (Van Dover et al. 2002). Even within a single site, hydrothermal vent habitats are very diverse, ranging from high-temperature chimney habitats to dif- fuse-flow areas (Haymon et al. 1991). Macrofaunal abundance and species richness can depend on various factors, including vent fluid chemistry and temperature, biological interactions, food availability, larval dispersal and recruitment (e.g. Micheli et al. 2002, Sarrazin et al. 2002, Mullineaux et al. 2003). Furthermore, the mechanisms that regulate community structure can vary along a gradient of hydrothermal fluid influence 
(e.g. Shank et al. 1998, Sarrazin et al. 1999, Mullineaux et al. 2003).

Riftia pachyptila is one of the most prominent endemic hydrothermal vent organisms on the East Pacific Rise (EPR) and, as a result of its symbiosis with chemoautotrophic bacteria, is effectively a primary producer (Childress \& Fisher 1992). Individuals of $R$. pachyptila can form dense aggregations with high biomass in diffuse-flow areas (e.g. Shank et al. 1998, Govenar et al. 2005). Temperatures around R. pachyptila aggregations generally range from 2 to $33^{\circ} \mathrm{C}$ and sulfide concentrations as high as 200 to $300 \mu \mathrm{M} \Sigma \mathrm{H}_{2} \mathrm{~S}$ (i.e. total concentration of labile species of sulfide) are commonly reached in these environments (Shank et al. 1998, Le Bris et al. 2006). The macrofaunal communities associated with aggregations of $R$. pachyptila at 2 chemically distinct sites on the EPR had densities up to 8200 ind. $\mathrm{m}^{-2}$ tube surface area (Govenar et al. 2005) and, in addition to megafauna and permanent macrofauna, Govenar et al. (2005) included all benthic juvenile/larval macrofauna (i.e. temporary meiofauna). The species richness of the macrofaunal communities was positively correlated with the surface area created by the tubeworms, and the latter was positively correlated with the total biomass of $R$. pachyptila. However, there were no statistically significant differences in abundance, biomass, species richness, Pielou's evenness or Shannon-Wiener diversity indices of the communities associated with $R$. pachyptila between sites (Govenar et al. 2005).

Only a few quantitative studies of hydrothermal vent meiobenthos, animals and protists passing through a sieve with $1 \mathrm{~mm}$ mesh-size and retained on a $63 \mu \mathrm{m}$ mesh sieve (Giere 1993), have been conducted. However, the importance of meiofauna for benthic communities in general is well-recognized. Meiofauna are essential for remineralization processes in the food web, because they have high turnover rates, short generation times, and can quickly respond to environmental changes (e.g. Giere 1993). Early studies have provided insights into meiobenthos at hydrothermal vents (Dinet et al. 1988, Shirayama 1992, Vanreusel et al. 1997); however, Zekely et al. (2006a) described the first quantitative meiobenthic community samples from hard-substrate mussel aggregations. Over 70 species of the vent-endemic siphonostomatoid copepods have been described from hydrothermal vents at various mid-ocean ridge regions (e.g. Humes 1987, Heptner \& Ivanenko 2002, Ivanenko \& Defaye 2006), but the harpacticoid copepods and other taxa, like nematodes or ostracods, are not as well known. In this study, we focused on the identification and quantification of the entire permanent meiobenthic community associated with the same aggregations of Riftia pachyptila studied by Govenar et al. (2005). One of the primary objectives of these coupled studies was to quantify and compare the abundance and community structure of the complex benthic communities (meiobenthic and macro/ megafaunal) associated with $R$. pachyptila at 2 chemically different hydrothermal vent sites.

\section{MATERIALS AND METHODS}

Collection sites. During cruises in December 2001 and December 2002, aggregations of Riftia pachyptila were collected from 2 different hydrothermal vent sites (Govenar et al. 2005). The sites, Tica $\left(9^{\circ} 50.447^{\prime} \mathrm{N}\right.$, $\left.104^{\circ} 17.493^{\prime} \mathrm{W}\right)$ and Riftia Field $\left(9^{\circ} 50.705^{\prime} \mathrm{N}, 104^{\circ}\right.$ $\left.17.493^{\prime} \mathrm{W}\right)$, are located in the axial summit trough of the EPR at $\sim 2500 \mathrm{~m}$ depth between the Clipperton and Siqueiros transform faults. The 2 sites are separated by $\sim 500 \mathrm{~m}$ and showed distinct chemical and biological characteristics at the time of sampling (Govenar et al. 2005, Le Bris et al. 2006). Tubeworms grew on hard substrate, and small amounts of sediment, mainly consisting of particulate organic matter (POM) with a few grains of basalt and sulfide precipitates, accumulated among the tubes.

In 2002, the fluid chemistry and maximum temperatures around the sampled Riftia pachyptila aggregations were measured with the 'ALCHIMIST' (Govenar et al. 2005, Le Bris et al. 2006). The tubeworm habitat at Tica (Fig. 1A) was characterized by warm fluids with maximum temperatures of $18^{\circ} \mathrm{C}$, maximum sulfide concentrations of $176 \mu \mathrm{M} \Sigma \mathrm{H}_{2} \mathrm{~S}$, and minimum $\mathrm{pH}$ close to neutrality. No iron was detected in the fluid (Le Bris et al. 2006). The anteriorly located gas-exchange organs of $R$. pachyptila (the 'plumes') were bright red, and the tubes were white (Govenar et al. 2005). At Riftia Field (Fig. 1B), maximum temperatures in the tubeworm habitat were a little higher (maximum measured temperature $=23^{\circ} \mathrm{C}$ ), but the maximum sulfide concentration was only $35 \mu \mathrm{M} \Sigma \mathrm{H}_{2} \mathrm{~S}$. Minimum $\mathrm{pH}$ values were as low as 5 in the diffuse flow, much lower than observed at Tica, and substantial concentrations of dissolved ferrous iron were present at this site (up to $42 \mu \mathrm{M}$ among the tubeworms) (Le Bris et al. 2006). The tubeworms exhibited pallid pink plumes, and the otherwise white tubes were covered in rust. The biomass of tubeworm aggregations was lower at Riftia Field than at Tica (Govenar et al. 2005).

Sample collections. Four quantitative samples were collected at each site using DSV 'Alvin' and a hydraulically actuated collection net, named 'Bushmaster Jr.' (Govenar et al. 2005; present Fig. 1C). Three of the collections from each site were used for the study of associated meiofauna reported here. TC1 and TC2 were collected from Tica in 2001 and correspond to TC1a and TC1b in Govenar et al. (2005), TC3 was collected 

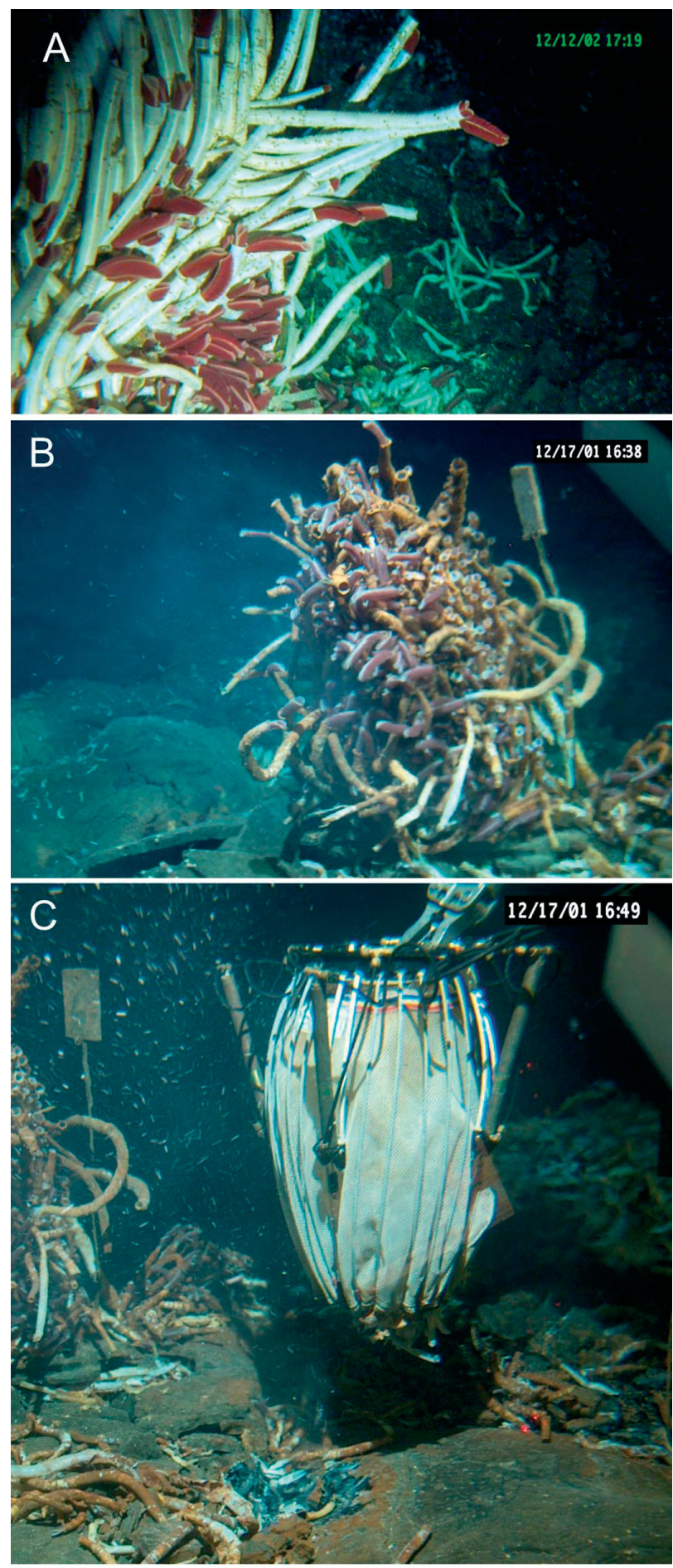

Fig. 1. In situ photograph at (A) Tica and (B) Riftia Field; both sites are located at $\sim 2500 \mathrm{~m}$ depth on the East Pacific Rise (near $9^{\circ} 50^{\prime} \mathrm{N}$ ). (C) In situ photograph of 'Bushmaster Jr.', sampling device that collected entire meio- and macrofauna community associated with aggregations of Riftia pachyptila

in 2002 and corresponds to TC2a in that study. Similarly, RF1 and RF2 were collected from Riftia Field in 2001 and correspond to RF1a and RF1b in Govenar et al. (2005), while RF3 was collected in 2002 and corresponds to RF2a in that study. For these quantitative collections, the Bushmaster Jr. sampling device was lined with a $63 \mu \mathrm{m}$ net. The Bushmaster Jr. was carefully positioned over an aggregation of tubeworms $<60 \mathrm{~cm}$ in diameter and was then tightly closed around the base of the tubeworms. After sampling, the closed Bushmaster Jr. was put into a holder, also lined with a $63 \mu \mathrm{m}$ net, on the basket of the DSV 'Alvin', with which it was transported to the surface and recovered on the deck of the RV 'Atlantis'. On board ship, all individuals of Riftia pachyptila were rinsed with cold filteredseawater and then removed from the collection for further processing. The length and the anterior diameter of every $R$. pachyptila tube were measured to obtain the surface area of the tubes in the aggregation (details in Govenar et al. 2005). Tubes were rinsed and carefully checked for attached epifauna (including foraminiferans and sessile ciliates). To extract the meiofauna community, samples were first passed through a $1 \mathrm{~mm}$ sieve and retained on a $63 \mu \mathrm{m}$ sieve, and were then fixed in $4 \%$ buffered formalin for $24 \mathrm{~h}$ and stored in $70 \%$ ethanol. A $63 \mu \mathrm{m}$ sieve was used because vent meiofauna are generally quite large, and we have never found vent meiofauna in the size fraction between 31 and $63 \mu \mathrm{m}$ at the EPR. The sample area ('footprint' of the collected aggregation on the seafloor) varied between 300 and $1300 \mathrm{~cm}^{2}$. In order to compare these variable sample sizes and relatively large samples of meiobenthos with each other and also with other meiofauna studies, abundance and biomass were standardized to a $10 \mathrm{~cm}^{2}$ sample ('footprint') area. There were no differences among trends after standardizing the data to either tube surface area or sediment volume (data not shown).

Quantification of abundance. The samples consisting of animals and sediment were placed in a graduated container and allowed to settle for $24 \mathrm{~h}$ to determine the sample volume. The quality of the sediment was visually characterized, and all animals were separated and identified to higher taxa under a dissecting microscope.

All individuals from the RF1 and RF2 samples were identified to the lowest possible taxon. In the other samples, at least 300 haphazardly chosen individuals of both nematodes and copepods were identified to species. Nematodes were mounted on slides using glycerine (Higgins \& Thiel 1988), and copepods were mounted on slides using a mixture of lactid acid and glycerine (1:3). The Nematoda were identified mainly according to Warwick et al. (1998), and the Copepoda according to Humes (1987) and Boxshall \& Halsey (2004). Unidentified Foraminifera were sent to G. Panieri, and Ostracoda to L. S. Kornicker, E. Harrison-Nelson, and R. Maddocks for further identification. 
Cumulative species-effort curves for copepods confirmed that the level of sampling effort was generally sufficient to describe the species richness of this group in the communities (Fig. 2B). No new nematode species were found after the first 30 individuals, identified in 4 of the samples. However, in TC2 and TC3 a single individual of a new species was detected after identifying 160 and 240 individuals, respectively, indicating that some very rare species may not have been detected (Fig. 2A).

Data on juvenile macrofauna (i.e. temporary meiofauna) that were in the size range of meiofauna were excluded from this study on permanent meiobenthos but were included in a description of the macrobenthos associated with tubeworms (Govenar et al. 2005). Planktonic copepods were also excluded from this study, because this community, albeit closely associated to the benthic environment, is not part of the meiobenthos (Giere 1993). Nine individuals of Platyhelminthes 1 specimen in TC2 and TC 3 each, 2 specimens in RF1, 5 specimens in RF2) were found, but could not be identified due to poor fixation and were not included in statistical analyses. Folliculinid (phylum Ciliophora) tubes were present in $\mathrm{TC} 2$, but were also omitted from the statistical analyses, because it was not possible to distinguish between empty and inhabited tubes after this method of fixation.

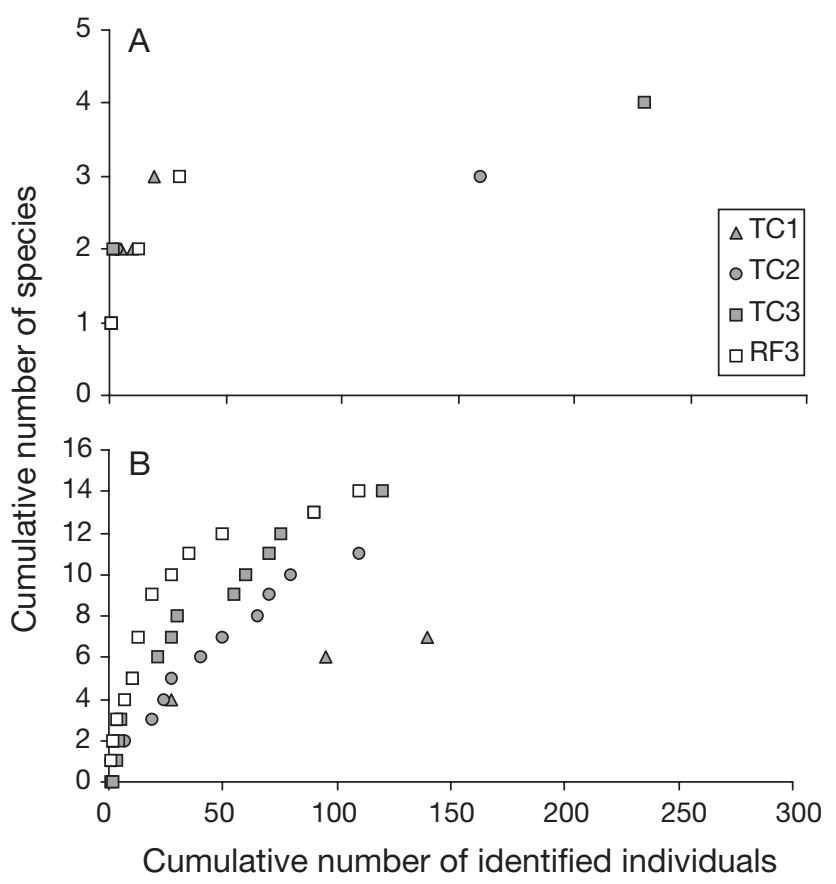

Fig. 2. Cumulative species-effort curves for (A) nematodes and (B) copepods based on cumulative number of species for samples with > 300 nematodes and copepods; TC1, TC2, TC3: Tica; RF3: Riftia Field
Quantification of biomass. The length and the width of all identified individuals were measured. The biomass of siphonostomatoid copepods was determined from the body form and the length, after Heptner \& Ivanenko (2002). The body volume of harpacticoid copepods was estimated according to McIntyre \& Warwick (1984), using the formula $V=L \times W^{2} \times C$, where $V=$ volume, $L=$ length, $W=$ width and $C=$ conversion factor, corresponding to body form of Harpacticoida; $C=400$ for pyriform body form. The body volume of nematodes was calculated using the formula $V=(L \times$ $\left.W^{2}\right) /\left(1.6 \times 10^{6}\right)$ according to Andrassy (1956). The test volume of foraminiferans was determined after Murray (1973) using a discus shape as an estimate for the foraminiferan test shape: $V=(\pi / 6) \times W \times L^{2}$, and the volume of foraminiferan biomass was estimated as $35 \%$ of the mean test volume according to Altenbach (1987). The estimated volumes of nematodes, harpacticoid copepods, and foraminiferans were then multiplied by the estimated specific gravity of 1.13 (for meiobenthos in general), following Feller \& Warwick (1998) to calculate the biomass (wet weight in $\mathrm{mg}$ ). The total biomass of each higher taxon separately and of all copepods, nematodes, and foraminiferans per sample was standardized to a $10 \mathrm{~cm}^{2}$ sampling area. No biomass calculations were made for ostracods and tanaidaceans because of their scarce abundance.

Ecological indices and analyses. The trophic status was assigned by discriminating between deposit-feeding primary consumers, and either parasitic or predatory secondary and tertiary consumers, based on the mouth structure of copepods following Heptner \& Ivanenko (2002) and the buccal cavity in nematodes following Wieser (1953).

To describe the meiobenthic community, the species richness $(S)$, Pielou's evenness index $\left(J^{\prime}\right)$, ShannonWiener diversity index $\left(H_{\text {loge }}^{\prime}\right)$ and estimated species richness (ESn) were calculated using the PRIMER Version 5 package (Plymouth Marine Laboratory; Clarke \& Gorley 2001). Student's $t$-tests were used to evaluate differences in abundance (square-root transformed), species richness (square-root transformed), biomass (ln transformed), sediment volume (ln transformed), tube surface area (ln transformed) and relative abundance (arcsine transformed), between Tica and Riftia Field. For Student's $t$-tests, data were transformed to fit a normal distribution. Because of the relatively low number of samples and high variances, we also tested for significant differences between sites for each parameter using bootstrapping (1000 resamplings each, 2-sided test, routine 'FTBOOT' from the package 'computerintensive statistics' by Nemeschkal 1999). Significance levels were Bonferroni-corrected ( $\left.p=\alpha / n_{;} \alpha=0.05\right)$, and significance of correlations among abundance, sediment volume, and tube surface 
area were identified using Pearson's r ( $F$-value and $t$-value calculations done using STATISTICA). To compare the community composition of samples within and between sites, dendrograms using PRIMER Version 5 were constructed from Bray-Curtis similarity values (Bray \& Curtis 1975). Abundances of species were standardized and then square-root transformed to down-weight the importance of very abundant species without losing the influence of the rarer species (Clarke \& Gorley 2001). Similarity percentage (SIMPER) analysis was used to determine which species were responsible for similarities within a site and dissimilarities between sites. Analysis of similarity (ANOSIM) was then used to evaluate differences in community structure between sites (Clarke \& Gorley 2001).

\section{RESULTS}

\section{Accumulated sediment and tube surface area}

Sediment in all samples consisted mainly of particulate organic matter (POM), with only a few grains of basalt, sulfide precipitates, coccoliths, and shells of pelagic foraminiferans. Larger organic particles, such as tubeworm plume remains and small pieces of tubes, mollusc gill filaments, eggs, as well as mucus and unidentifiable degraded organic material, were present. Overall, very little sediment had accumulated between tubeworms. Sediment volume ranged from 1.5 to $5.5 \mathrm{ml} 10 \mathrm{~cm}^{-2}$ at Tica and from 0.3 to $1.1 \mathrm{ml}$ $10 \mathrm{~cm}^{-2}$ at Riftia Field (Table 1). Although sediment volume and the tube surface area of Riftia pachyptila was higher in all samples from Tica than those from Riftia Field (Table 1), these differences were not statistically discernible (Table 2). Sediment volume and tube surface area were positively correlated at both sites $(r=0.88, p=0.03)$.

\section{Abundance}

The meiobenthos contributed between 0.9 and $15 \%$ to the total abundance of the benthic communities associated with Riftia pachyptila, except in sample TC2, where the meiobenthos comprised $71 \%$ of the total abundance. Numbers of permanent meiobenthos ranged from 60 to 29279 ind. sample ${ }^{-1}$ and was positively correlated with the volume of sediment $(\mathrm{r}=0.99$, $\mathrm{p}<0.001)$ and tube surface area $(\mathrm{r}=0.89, \mathrm{p}=0.018)$ in the samples. The abundances standardized to an area of $10 \mathrm{~cm}^{2}$ also ranged considerably among samples. The minimum abundance at Tica (20 ind. $10 \mathrm{~cm}^{-2}$ ) was higher than the maximum abundance at Riftia Field (12 ind. $10 \mathrm{~cm}^{-2}$ ) (Table 1), but the difference between sites was not discernible statistically (Table 2). Nematodes, copepods, foraminiferans, ostracods, and platyhelminthes were present at both sites, but tanaidaceans were collected only at Riftia Field and folliculinid ciliates were only found at Tica. The differences in the abundances of the 2 most prevalent taxa, nematodes and copepods, were also not statistically discernible between Riftia Field and Tica (Table 2), although nematodes clearly dominated the Tica communities and were more abundant in every collection from Tica (16 to 946 ind. $10 \mathrm{~cm}^{-2}$ ) than in any from Riftia Field ( $<1$ to 7 ind. $10 \mathrm{~cm}^{-2}$ ) (Table 1). The abun-

Table 1. Characteristics of 3 samples from each site, showing sample area, tube surface area of Riftia pachyptila, and sediment volume, for each aggregation, and abundance and biomass for higher taxa, together with total values and values $10 \mathrm{~cm}^{-2}$; $\mathrm{TC} 1$, TC2, TC3: Tica; RF1, RF2, RF3: Riftia Field

\begin{tabular}{|c|c|c|c|c|c|c|c|c|c|c|c|c|}
\hline \multirow[t]{2}{*}{ Parameter } & \multicolumn{2}{|c|}{$\mathrm{TC} 1$} & \multicolumn{2}{|c|}{$\mathrm{TC} 2$} & \multicolumn{2}{|c|}{ TC3 } & \multicolumn{2}{|c|}{ RF1 } & \multicolumn{2}{|c|}{ RF2 } & \multirow{2}{*}{\multicolumn{2}{|c|}{$\begin{array}{c}\text { RF3 } \\
\text { Total } 10 \mathrm{~cm}^{-2}\end{array}$}} \\
\hline & Total & $10 \mathrm{~cm}^{-2}$ & Total & $10 \mathrm{~cm}^{-2}$ & Total & $10 \mathrm{~cm}^{-2}$ & Total & $10 \mathrm{~cm}^{-2}$ & Total & $10 \mathrm{~cm}^{-2}$ & & \\
\hline \multicolumn{13}{|c|}{ Environmental characteristics } \\
\hline Sample area $\left(\mathrm{cm}^{2}\right)$ & 600 & & 300 & & 700 & & 1300 & & 600 & & 800 & \\
\hline Tube surface area $\left(\mathrm{cm}^{2}\right)$ & 52300 & 872 & 65500 & 2183 & 38000 & 543 & 9600 & 74 & 18300 & 305 & 26600 & 333 \\
\hline Sediment (ml) & 88 & 1.47 & 165 & 5.5 & 133 & 1.9 & 40 & 0.31 & 37 & 0.62 & 85 & 1.06 \\
\hline \multicolumn{13}{|c|}{ Abundance (no. individuals) } \\
\hline Nematoda & 951 & 15.85 & 28369 & 945.63 & 3237 & 46.24 & 20 & 0.15 & 11 & 0.18 & 573 & 7.16 \\
\hline Copepoda & 217 & 3.62 & 807 & 26.90 & 983 & 14.04 & 25 & 0.19 & 48 & 0.80 & 342 & 4.27 \\
\hline Foraminifera & 51 & 0.85 & 99 & 3.30 & 21 & 0.30 & 20 & 0.15 & 1 & 0.02 & 48 & 0.60 \\
\hline Ostracoda & 0 & 0 & 4 & 0.13 & 1 & 0.01 & 0 & 0 & 0 & 0 & 15 & 0.19 \\
\hline Tanaidacea & 0 & 0 & 0 & 0 & 0 & 0 & 0 & 0 & 0 & 0 & 3 & 0.04 \\
\hline Total abundance & 1219 & 20.32 & 29279 & 975.97 & 4242 & 60.59 & 65 & 0.50 & 60 & 1.00 & 981 & 12.26 \\
\hline \multicolumn{13}{|l|}{ Biomass (mg wet wt) } \\
\hline Nematoda & 0.129 & 0.002 & 4.913 & 0.164 & 0.406 & 0.006 & 0.004 & 0.001 & 0.001 & 0.001 & 0.079 & 0.001 \\
\hline Copepoda & 19.319 & 0.322 & 86.501 & 2.883 & 95.756 & 1.368 & 2.525 & 0.019 & 4.783 & 0.080 & 33.436 & 0.418 \\
\hline Total biomass & 19.448 & 0.324 & 91.414 & 3.047 & 96.162 & 1.374 & 2.529 & 0.019 & 4.78 & 0.080 & 33.515 & 0.419 \\
\hline
\end{tabular}


Table 2. Results of Student's $t$-test $\left(t_{4 \mathrm{df}}\right)$ and bootstrapping (bt, 1000 resamplings each, 2-sided test) used to test for significant differences in environmental and community characteristics between sites. All calculations were made for values $10 \mathrm{~cm}^{-2}$ and additionally for relative abundance and species richness of higher taxa. Shannon-Wiener diversity indices $\left(H_{\text {loge }}^{\prime}\right)$ were tested by bootstrapping. All results are classical Bonferroni-corrected (Bonf. corr.); sig = significant; ns = not significant

\begin{tabular}{|c|c|c|c|c|c|}
\hline & $t_{4 \mathrm{df}}(2.776)$ & $\mathrm{p}(t$-test $)$ & Bonf. corr. ( $t$-test) & $\mathrm{p}(\mathrm{bt})$ & Bonf. corr. (bt) \\
\hline Sediment $\left(10 \mathrm{~cm}^{-2}\right)$ & 2.68 & 0.06 & ns & 0.016 & $\mathrm{~ns}$ \\
\hline Tube surface area $\left(10 \mathrm{~cm}^{-2}\right)$ & 2.58 & 0.06 & $\mathrm{~ns}$ & 0.014 & ns \\
\hline \multicolumn{6}{|l|}{ Abundance } \\
\hline Total $\left(10 \mathrm{~cm}^{-2}\right)$ & 1.52 & 0.21 & $\mathrm{~ns}$ & 0.032 & $\mathrm{~ns}$ \\
\hline Nematoda $\left(10 \mathrm{~cm}^{-2}\right)$ & 1.49 & 0.21 & $\mathrm{~ns}$ & 0.008 & $\mathrm{~ns}$ \\
\hline Copepoda $\left(10 \mathrm{~cm}^{-2}\right)$ & 2.32 & 0.08 & $\mathrm{~ns}$ & 0.026 & ns \\
\hline \multicolumn{6}{|l|}{ Relative abundance } \\
\hline Nematoda (\%) & 3.30 & 0.03 & $\mathrm{~ns}$ & 0.764 & ns \\
\hline Copepoda (\%) & -2.36 & 0.07 & ns & $<0.0027$ & $\operatorname{sig}$ \\
\hline Biomass $\left(10 \mathrm{~cm}^{-2}\right)$ & 2.30 & 0.08 & $\mathrm{~ns}$ & 0.018 & ns \\
\hline \multicolumn{6}{|l|}{ Species richness } \\
\hline Total & 0.34 & 0.75 & ns & 0.692 & ns \\
\hline Nematoda & 1.91 & 0.13 & $\mathrm{~ns}$ & 0.038 & ns \\
\hline Copepoda & 0.56 & 0.60 & ns & 0.484 & ns \\
\hline \multicolumn{6}{|l|}{$H_{\text {loge }}^{\prime}$} \\
\hline Total & & & & $<0.0027$ & sig \\
\hline Nematoda & & & & 0.826 & ns \\
\hline Copepoda & & & & 0.876 & ns \\
\hline
\end{tabular}

dance of copepods ranged from 4 to 27 ind. $10 \mathrm{~cm}^{-2}$ at Tica and from $<1$ to 4 ind. $10 \mathrm{~cm}^{-2}$ at Riftia Field. The abundance of foraminiferans, ostracods and tanaidaceans was always $<1$ ind. $10 \mathrm{~cm}^{-2}$, except in TC2 where 3 foraminiferans $10 \mathrm{~cm}^{-2}$ were present (Table 1). At Tica, nematodes dominated with a relative abundance of $84 \pm 11 \%$, followed by copepods with $15 \pm 11 \%$. In contrast, at Riftia Field copepods reached $51 \pm 25 \%$, nematodes accounted for $36 \pm 21 \%$, and foraminiferans had variable relative abundances of $12 \pm 16 \%$. The relative abundance of copepods, but not the abundance of nematodes and foraminiferans, was statistically significantly different between the 2 sites (Table 2).

\section{Biomass}

Meiobenthic biomass made up less than $0.0001 \%$ of the total community biomass at both sites (for macrobenthic biomass see Govenar et al. 2005). There was no statistically detectable difference in the total meiobenthic biomass between Tica and Riftia Field (Table 2). The meiobenthic biomasses ranged from 0.3 to $3 \mathrm{mg}$ wet wt $10 \mathrm{~cm}^{-2}$ in Tica samples and from 0.02 to $0.4 \mathrm{mg} 10 \mathrm{~cm}^{-2}$ at Riftia Field. Dirivultid copepods with body lengths of $<2 \mathrm{~mm}$ made up the majority of biomass at both sites. Nematode biomass was low in all samples except TC2, which contained a relatively large number of nematodes with a biomass of $0.16 \mathrm{mg}$ wet wt $10 \mathrm{~cm}^{-2}$. Foraminiferans never exceeded a biomass of $0.001 \mathrm{mg}$ wet wt $10 \mathrm{~cm}^{-2}$ due to their low abundances (Table 1).

\section{Diversity indices}

A total of 33 meiobenthic species was identified from the 6 sampled tubeworm aggregations. The lowest and highest species richness ( 9 and 25 species) were found at Riftia Field (RF2 and RF3, respectively), whereas the species richness varied from 11 to 20 species at Tica (Table 3). The 2 sites shared 19 species. Five species were exclusively found at Tica (2 nematodes, 3 copepods) and 9 species were collected only at Riftia Field (1 nematode, 4 copepods, 1 foraminiferan, 2 ostracods, and 1 tanaidacean). Pielou's evenness index was variable within and between sites, ranging from 0.15 (TC2) to 0.87 (RF1), and was always higher at Riftia Field than at Tica (Table 3). Overall, the Shannon-Wiener diversity indices of the entire meiobenthic community were low at both sites $\left(H^{\prime}\right.$ loge 0.44 to 2.00$)$. The Shannon-Wiener diversity index was, however, statistically significantly higher at Riftia Field than at Tica ( $\mathrm{p}<$ 0.0027 , Table 2). The trophic diversity of the meiobenthos community was also low at both sites. Primary consumers dominated in all samples (Tica, 87 to $100 \%$; Riftia Field, 83 to $100 \%$ ). All species belonged to firstorder primary consumers, except for 3 parasitic copepod species in the genus Ceuthocetes. 
Table 3. Species richness $(S)$, Pielou's evenness index $\left(J^{\prime}\right)$ and Shannon-Wiener diversity index $\left(H_{\text {loge }}^{\prime}\right)$ for total meiobenthos, Nematoda, and Copepoda calculated for all 6 samples and estimated species richness (ESn) is shown for total meiobenthos. TC1, TC2, TC3: Tica; RF1, RF2, RF3: Riftia Field

\begin{tabular}{|lcccccc|}
\hline Parameter & TC1 & TC2 & TC2 & RF1 & RF2 & RF3 \\
\hline \multicolumn{2}{l}{ Total meiobenthos } & & & & & \\
$\quad S$ & 11 & 17 & 20 & 10 & 9 & 25 \\
$J^{\prime}$ & 0.47 & 0.15 & 0.45 & 0.87 & 0.82 & 0.54 \\
$H_{\text {loge }}^{\prime}$ & 1.12 & 0.44 & 1.35 & 2 & 1.79 & 1.75 \\
$\quad$ ES(100) & 7.57 & 4.92 & 11.12 & 10 & 9 & 14.25 \\
Nematoda & & & & & & \\
$S$ & 3 & 3 & 4 & 2 & 1 & 3 \\
$J^{\prime}$ & 0.41 & 0.24 & 0.34 & 0.97 & 1 & 0.31 \\
$H_{\text {loge }}^{\prime}$ & 0.45 & 0.27 & 0.47 & 0.67 & 0 & 0.35 \\
Copepoda & & & & & & \\
$S$ & 7 & 11 & 14 & 6 & 7 & 14 \\
$J^{\prime}$ & 0.67 & 0.6 & 0.85 & 0.85 & 0.79 & 0.75 \\
$H_{\text {loge }}^{\prime}$ & 1.30 & 1.44 & 2.26 & 1.53 & 1.53 & 1.99 \\
\hline
\end{tabular}

The species richness of the nematode community was also low, with only 1 species found in RF2 and the maximum (4 species) found in TC3. The copepod species richness was higher and ranged from 6 to 14 . Neither the species richness nor the Shannon-Wiener diversity indices of nematodes or copepods were significantly different between sites (Table 2).

\section{Relative abundance of species}

All identified meiobenthic species and their relative abundances are listed in Table 4 . A total of only 5 nematode species and 15 copepod species belonging to the vent endemic family of Dirivultidae (order Siphonostomatoida) were present. Five harpacticoid species were also identified, but these were present in relatively low numbers. In addition, 4 ostracod species, 1 tanaidacean and 3 foraminiferan species were identified, but all of them except the foraminiferan Abyssotherma pacifica were rare at both sites; $45 \%$ of the total meiobenthic species (15 of 33) had not yet been formally described at the time of collection. The following species correspond with those listed in Zekely et al. (2006a): Chromadorita sp. 1; Halomonhystera hickeyi (described in Zekely et al. 2006b, corresponds to Monhysteridae sp. 1 in Zekely et al. 2006a); Thalassomonhystera fisheri (described in Zekely et al. 2006b, corresponds to Thalassomonhystera sp. 1 in Zekely et al. 2006a); and Halectinosoma sp. 1. The nematodes Halomonhystera sp. 1 and Daptonema sp. 1, 2 harpacticoid copepod species (Harpacticoida sp. 1 and sp. 2), 2 foraminiferan species (Deuterammina sp. 1, Foraminifera sp. 1), 4 ostracod species (Polycopetta pax, Thomontocypris brightae, Thomontocypris goll- nerae and Xylocythere vanharteni: see Desbruyères et al. 2006) and 1 tanaidacean species were found for the first time.

At Tica, the meiobenthic community was dominated by the nematode Thalassomonhystera fisheri, which accounted for 64 to $91 \%$ of the relative abundance of meiobenthos at this site. The species with next highest relative abundance at Tica was the nematode Halomonhystera sp. 1 (3 to $12 \%$ ), a species not present at Riftia Field. No other species accounted for more than $5 \%$ of the total abundance in any collection from Tica. A more even distribution of abundance among species was found at Riftia Field, where no single species or taxonomic group was dominant in all samples. At RF1, the most abundant species was the foraminiferan Abyssotherma pacifica (28\% of the meiobenthic abundance), while at RF2, the copepod Benthoxynus tumidiseta, a species not present in RF1 and RF3, was most abundant $(25 \%)$, and at RF3, the nematode Halomonhystera hickeyi was the dominant species (52\%) (Table 4).

\section{Community patterns}

The dendrogram (based on Bray-Curtis community similarity) grouped the meiobenthic community samples by site (Fig. 3). The nematode species Thalassomonhystera fisheri contributed on average $36.3 \%$ to the $66.3 \%$ similarity among the 3 samples from Tica (SIMPER). Compared to Tica, Riftia Field samples had a lower average similarity of $48.8 \%$. The nematode Halomonhystera hickeyi and the copepod Scotocetes introrsus contributed 13.2 and $11.7 \%$, respectively, to the similarity among the 3 Riftia Field samples. SIMPER analysis revealed an overall similarity of only $31.5 \%$ between the 2 sites. ANOSIM did not detect statistically significant differences in the community structure between the 2 sites, perhaps because of the relatively low number of samples (global $\mathrm{R}=1 ; \mathrm{p}=0.1$, number of permutations 10).

\section{DISCUSSION}

Meiobenthos associated with aggregations of the tubeworm Riftia pachyptila on the EPR near $9^{\circ} 50^{\prime} \mathrm{N}$ can be characterized as a relatively species poor, epibenthic hard-substrate community of a few protist and metazoan taxa, represented by both vent endemic and generalist species, occurring in low abundance and biomass. The maximum sizes of many of the species are impressively large for meiobenthos, with nematodes reaching $900 \mu \mathrm{m}$ in length and copepods as long as $2 \mathrm{~mm}$. The general picture of vent meiobenthos 
Table 4. Relative abundance of meiobenthic species. Copepodites: all stages of Platyhelminthes and folliculinid ciliates (Ciliophora): these were found but are not included in statistical analysis because identification to speciel level was not possible due to method of fixation for the former, and no distinction between live protists and empty tubes was possible for the latter. p: present; a: absent. TC1, TC2, TC3: Tica; RF1, RF2, RF3: Riftia Field. Relative abundances $>10 \%$ are marked in bold

\begin{tabular}{|c|c|c|c|c|c|c|}
\hline Taxon & TC1 & TC2 & TC3 & RF1 & RF2 & RF3 \\
\hline \multicolumn{7}{|l|}{ Nematoda } \\
\hline Chromadorita sp. 1 & 0 & 0 & 0.3 & 0 & 0 & 0 \\
\hline Halomonhystera sp. 1 & 6.0 & 3.0 & 11.7 & 0 & 0 & 0 \\
\hline Halomonhystera hickeyi & 3.5 & 2.7 & 0.3 & 12.3 & 18.3 & 52.3 \\
\hline Thalassomonhystera fisheri & 68.5 & 91.1 & 64.1 & 18.5 & 0 & 5.9 \\
\hline Daptonema sp. 1 & 0 & 0 & 0 & 0 & 0 & 0.2 \\
\hline \multicolumn{7}{|l|}{ Copepoda } \\
\hline Aphotopontius acanthinus & 0.1 & 0 & 2.3 & 0 & 0 & 0 \\
\hline Aphotopontius flexispina & 0 & 0 & 0.1 & 0 & 0 & 0 \\
\hline Aphotopontius hydronauticu & s 0.2 & 0 & 2.0 & 1.5 & 0 & 1.3 \\
\hline Aphotopontius mammilatus & 0 & 0.01 & 2.0 & 0 & 0 & 0.4 \\
\hline Aphotopontius probolus & 0.3 & 0 & 1.5 & 3.1 & 0 & 0.4 \\
\hline Aphotopontius rapunculus & 0.1 & 0 & 0.6 & 0 & 0 & 0 \\
\hline Bathylaophonte pacifica ${ }^{\mathrm{a}}$ & 0 & 0.01 & 0 & 0 & 3.3 & 0 \\
\hline Benthoxynus tumidiseta & 0 & 0.4 & 0.3 & 0 & 25.0 & 0 \\
\hline Ceuthocetes acanthotrix & 3.6 & 0.1 & 3.0 & 0 & 0 & 1.3 \\
\hline Ceuthocetes aliger & 4.8 & 0.05 & 3.2 & 0 & 0 & 1.7 \\
\hline Ceuthocetes introversus & 4.2 & 0.1 & 2.8 & 0 & 16.7 & 1.3 \\
\hline Halectinosoma sp. $1^{\mathrm{a}}$ & 0 & 0.1 & 0.4 & 1.5 & 0 & 0 \\
\hline Harpacticoida sp. $1^{\mathrm{a}}$ & 0 & 0 & 0 & 0 & 0 & 0.2 \\
\hline Harpacticoida sp. $2^{\mathrm{a}}$ & 0 & 0 & 0 & 0 & 3.3 & 0.4 \\
\hline Scotocetes introrsus & 0 & 1.5 & 0.3 & 16.9 & 10.0 & 10.9 \\
\hline Stygiopontius flexus & 0 & 0.1 & 0.3 & 6.2 & 1.7 & 2.6 \\
\hline Stygiopontius hispidulus & 0 & 0.03 & 0 & 0 & 0 & 1.9 \\
\hline Stygiopontius mucroniferus & 0 & 0 & 0 & 0 & 0 & 0.2 \\
\hline Stygiopontius stabilitus & 0 & 0 & 0 & 0 & 0 & 0.2 \\
\hline Xylora bathyalis ${ }^{\mathrm{a}}$ & 0 & 0.2 & 0.2 & 7.7 & 1.7 & 4.7 \\
\hline Copepodites & 4.6 & 0.3 & 4.3 & 1.5 & 18.3 & 7.3 \\
\hline \multicolumn{7}{|l|}{ Formaminifera } \\
\hline Abyssotherma pacifica & 4.2 & 0.3 & 0.5 & 27.7 & 1.7 & 4.1 \\
\hline Deuterammina sp. 1 & 0 & 0.04 & 0 & 3.1 & 0 & 0.7 \\
\hline Foraminifera sp. 1 & 0 & 0 & 0 & 0 & 0 & 0.1 \\
\hline \multicolumn{7}{|l|}{ Ostracoda } \\
\hline Polycopetta pax & 0 & 0 & 0 & 0 & 0 & 0.1 \\
\hline Thomontocypris brightae & 0 & 0 & 0.02 & 0 & 0 & 0.8 \\
\hline Thomontocypris gollnerae & 0 & 0 & 0 & 0 & 0 & 0.2 \\
\hline Xylocythere vanharteni & 0 & 0.01 & 0 & 0 & 0 & 0.4 \\
\hline \multicolumn{7}{|l|}{ Tanaidacea } \\
\hline Tanaidacea sp. 1 & 0 & 0 & 0 & 0 & 0 & 0.3 \\
\hline Platyhelminthes & a & $\mathrm{p}$ & $\mathrm{p}$ & $\mathrm{p}$ & $\mathrm{p}$ & $\mathrm{a}$ \\
\hline Ciliophora & $\mathrm{a}$ & $\mathrm{p}$ & $\mathrm{a}$ & $\mathrm{a}$ & $\mathrm{a}$ & $\mathrm{a}$ \\
\hline${ }^{\mathrm{a}}$ Harpacticoid copepods & & & & & & \\
\hline
\end{tabular}
copepodites were found, but identification to species level was not possible;

EPR and the Mid-Atlantic Ridge (Zekely et al. 2006a), as well as sedimented vent communities at the Guayamas Basin (Dinet et al. 1988). However, the low abundance of vent meiobenthos stands in clear contrast to the abundances of meiobenthos from most other marine habitats. Marine sands are typically inhabited by interstitial meiobenthos ranging from 1000 to 2000 ind. $10 \mathrm{~cm}^{-2}$ (see Higgins \& Thiel 1988, Giere 1993), and the abundances of epibenthic communities on hard substrates normally exceed 100 ind. $10 \mathrm{~cm}^{-2}$ (Danovaro \& Fraschetti 2002, Atilla et al. 2003). At deep-sea cold seeps, abundances are consistently $>100$ ind. $10 \mathrm{~cm}^{-2}$ and can reach 100 times this density (Palmer et al. 1988, Olu et al. 1997). Only in deep-sea clays and oozes are low abundances similar to vents reported. However, these are considered the exception rather than the rule, since densities of between 100 and 6000 ind. $10 \mathrm{~cm}^{-2}$ are much more typical (see Soltwedel 2000).

Hydrothermal vents, in general, appear to harbor relatively few higher taxa of meiofauna: only nematodes, copepods, ostracods, platyhelminthes, mites, tanaidaceans, ciliophorans, and foraminiferans have been reported from vents (Dinet et al. 1988, Shirayama 1992, Zekely et al. 2006a). Nematodes and siphonostomatoid copepods dominate the vent meiofauna communities on the EPR, while all other taxa are rare (Zekely et al. 2006a). This stands in contrast to many shallow-water sediments, where nematodes, harpacticoid copepods, and platyhelminthes dominate the meiofauna (Giere 1993). Numerous other meiobenthic taxa including for example hydroids, gnathostomulids, nemerteans, gastrotrichs, loriciferans, and tardigrades are commonly found in emerging from the few studies conducted in other vent habitats mirrors the community structure that we found among tubeworm aggregations at the EPR (Dinet et al. 1988, Shirayama 1992, Vanreusel et al. 1997, Tsurumi et al. 2003, Zekely et al. 2006a).

Abundances well below 100 ind. $10 \mathrm{~cm}^{-2}$ are common for hard-substrate vent communities, such as those dominated by either tubeworms or mussels at the other shallow-water and deep-sea habitats (Giere 1993), but have not yet been reported from hydrothermal vents.

The epibenthic hard-substrate meiobenthic community associated with Riftia pachyptila dwells in a structurally diverse habitat. At our EPR study sites, tubeworms grow in dense aggregations of up to thousands of individuals $\mathrm{m}^{-2}$ on hard substrate and individual 


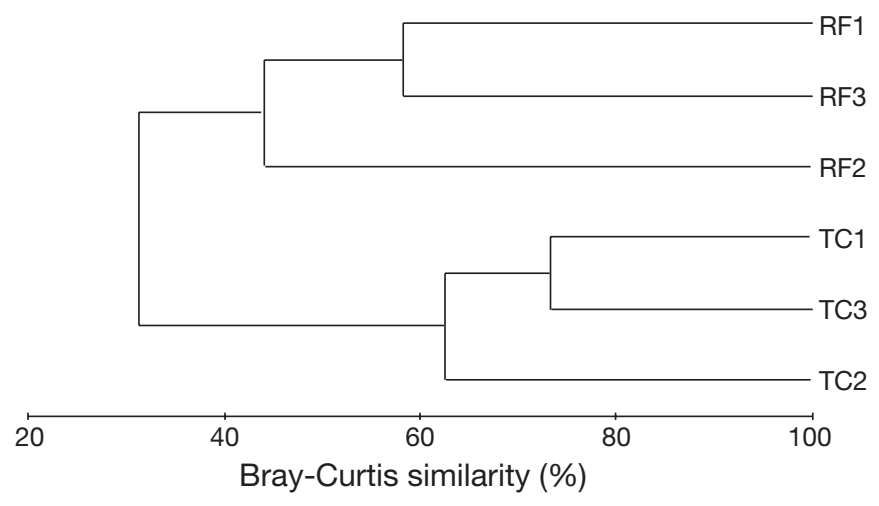

Fig. 3. Hierachical cluster diagram of group-average linking, based on Bray-Curtis community similarity values from the 6 samples; TC1, TC2, TC3: Tica; RF1, RF2, RF3: Riftia Field

R. pachyptila tubes can reach more than $2 \mathrm{~m}$ in length. Such clumps of tubeworms create a 3-dimensional habitat and extensive tube surface areas 10 to 200 times larger than the area of the rock substrate where they occur (Govenar et al. 2005). Whether the meiobenthic organisms live on the basalt, on the tubes, and/or in the sediment remains to be resolved. In situ observations of such small animals in this habitat are very difficult to obtain, and observations of live animals in retrieved samples may not reflect in situ behavior. We have seen copepods crawling on $R$. pachyptila tubes as well as on sediment, and nematodes were found in little sediment clumps but were also observed to crawl on the surface of basalt. Both tube surface area and the sediment volume accumulating within these aggregations are correlated with the abundance of associated meiobenthos (and with each other). This suggests that either tube surface area or sediment volume (or both) is important to the meiobenthos community. As tubeworms grow in size and their number increases, sediment accumulates within the aggregation and the abundance of meiobenthos increases. A similar situation was found with a shallow-water hardsubstrate nematode community, in which colonization was related to the amount of sediment trapped by algal growth on a rocky surface (Danovaro \& Fraschetti 2002).

The low abundance and biomass of meiobenthos in the majority of our samples were surprising, because the high levels of POM apparently support high abundances of detrivorous macrofaunal species cooccurring in tubeworm aggregations (e.g. Tunnicliffe 1991, Sarrazin et al. 1999, Colaço et al. 2002, Tsurumi \& Tunnicliffe 2003), including the aggregations that we studied (Govenar et al. 2005). The low meiobenthic abundance is difficult to explain. In vent habitats, high quantities of low-quality POM available for deposit feeders and predation of meiofauna by the highly abundant macrofauna might contribute to bottom-up as well as top-down regulation (e.g. Ólafsson \& Moore 1990, Fabiano \& Danovaro 1999, Levesque \& Juniper 2002, Micheli et al. 2002, Ólafsson 2003, Levesque et al. 2005) .

The majority of species in the meiobenthic community associated with tubeworm aggregations on the EPR belong to the vent endemic family Dirivultidae. Siphonostomatoid copepods (to which the dirvultids belong) dominate the copepod communities at vents studied so far (Tsurumi et al. 2003, Gollner et al. 2006, Zekely et al. 2006a), although a higher diversity of copepods was found in areas with little or no detectable hydrothermal fluid on the Juan de Fuca Ridge (Tsurumi et al. 2003). The low number and diversity of nematode genera among the tubeworm aggregations in this study stands in contrast to the nematode communities associated with mussel aggregations at other vent sites $\left(9\right.$ genera, $11^{\circ} \mathrm{N} \mathrm{EPR} ;$ genera, $23^{\circ} \mathrm{N}$ Mid-Atlantic Ridge, Zekely et al. 2006a; 15 genera, Iheya Ridge, Shirayama 1992; 31 genera, North Fiji Basin, Vanreusel et al. 1997). Furthermore, the nematode species richness is the lowest ever recorded from hydrothermal vents and, to our knowledge, the lowest ever recorded in a marine habitat (e.g. Higgins \& Thiel 1988, Giere 1993). Whether or not these species are restricted to environments typified by chemosynthetic primary production, or are also found in non-chemosynthetic influenced habitats remains to be tested.

Meiobenthos in tubeworm aggregations are exposed to fluctuating physical and chemical conditions. Most of the vent meiobenthos is mobile and potentially capable of avoiding unfavorable conditions within this heterogeneous habitat. Nevertheless, they may also have to tolerate a certain degree of exposure to hypoxic conditions and to toxic sulfide and acidic $\mathrm{pH}$. The 2 discrete sites of low-temperature hydrothermal activity, Tica and Riftia Field, were characterized by similar moderate temperatures with maxima of $18^{\circ} \mathrm{C}$ at Tica and $23^{\circ} \mathrm{C}$ at Riftia Field, but exhibited differences in $\mathrm{pH}$ and levels of $\Sigma \mathrm{H}_{2} \mathrm{~S}$ and $\mathrm{Fe}^{2+}$ when surveyed in 2002 (Le Bris et al. 2006). Thus, at least by December 2002, meiobenthos at Tica was probably exposed to higher concentrations of sulfide $\left(176 \mu \mathrm{M} \Sigma \mathrm{H}_{2} \mathrm{~S}\right)$ and neutral $\mathrm{pH}$, while at Riftia Field sulfide concentrations were more moderate (up to $35 \mu \mathrm{M} \Sigma \mathrm{H}_{2} \mathrm{~S}$ ), and the $\mathrm{pH}$ was more acidic. This low $\mathrm{pH}$ favors the molecular $\mathrm{H}_{2} \mathrm{~S}$ form over $\mathrm{HS}^{-}$, enhancing the capacity for sulfide to diffuse across biological membranes (Visman 1991).

At first glance, the meiobenthic communities at Tica and Riftia Field appear similar despite the very different chemical characteristics of the 2 sites. The total species richness of Tica (24 species) and Riftia Field (28 species) is similar, and there were no statistically 
detectable differences in either the abundance or biomass of the total meiobenthic community. Moreover, the majority of specimens at both sites were either copepods or nematodes. ANOSIM did not detect statistically significant differences between sites, but the global $R(R=1)$ suggests that there are some differences between the communities at Tica and Riftia Field. The differences between the meiobenthic communities were evident in the Pielou's evenness index and Shannon-Wiener species diversity index, which were statistically significantly higher at Riftia Field ( $H_{\text {loge }}^{\prime} 1.75$ to 2.0$)$ than at Tica ( $H_{\text {loge }}^{\prime} 0.44$ to 1.35$)$. The distribution of abundance among species or in the dominant species may have contributed to the $>70 \%$ dissimilarity between sites. The statistical differences in the meiobenthic communities between these 2 sites may be because of shifts in the relative abundance of some species, as well as unique occurrences of some species. Although conclusions from these patterns can only be drawn with upmost caution, due to the limited number of samples, the dominance of nematodes and the lower species diversity at Tica may be due to differences in chemical characteristics between the 2 sites.

Meiobenthos associated with tubeworm aggregations on the EPR is relatively species-poor and of relatively low abundance, but the present description contributes considerably to our knowledge of biodiversity at hydrothermal vents. The community associated with tubeworms includes 24 meiofauna and 34 macrofauna species at Tica and 28 meiofauna species and 33 macrofauna species at Riftia Field. Altogether, a total of 79 species were found associated with tubeworms at the 2 sites, 46 macrofauna and 33 meiofauna species (Govenar et al. 2005). Thus, $41 \%$ of the total species richness is meiobenthos. Interestingly, some of the differences in the meiobenthic community structure between the high-sulfide Tica site and the low-sulfide Riftia Field site were not detectable in the marcrofauna community in the same samples. In this larger size fraction, none of the univariate measures of community structure $\left(S, J^{\prime}, H_{\text {loge, }}^{\prime}\right.$ abundance, biomass) were significantly different between sites. This is also supported by the dendrograms (Bray-Curtis similarity), in which the macrofaunal communities have a similarity of about $70 \%$ (Govenar et al. 2005) whereas the meiobenthic communities from the 2 different sites only show a similarity of about $35 \%$. Understanding the basis of these apparently different responses to differences in the vent environment must await further study.

Acknowledgements. This work was supported by the Austrian Science Foundation grant FWF (P16774-B03 to M.B.), US National Science Foundation grant (OCE-0002729 to C.R.F.), Ifremer and the European Community (Ventox project EVK3-
1999-00056P to N.L.B.), and the International Office Vienna and Promotion Grants from the University of Vienna (to J.Z. and S.G.). We thank the captain and crew of the RV 'Atlantis' and the pilots and crew of the DSV 'Alvin' for their expertise and assistance in shipboard and submersible operations on the 2001 (AT 7-05) and 2002 (AT 7-26) cruises to the East Pacific Rise. We also thank the taxonomists L. S. Kornicker, E. Harrison-Nelson, and R. Maddocks for the identification of ostracods, and G. Panieri for the identification of foraminiferans. D. Danielopol, R. Huys, V. N. Ivanenko and P. MartínezArbizu also assisted in taxonomy.

\section{LITERATURE CITED}

Altenbach AV (1987) The measurement of organic carbon in Foraminifera. J Foraminifer Res 17:106-109

Andrassy I (1956) Die Rauminhalts- und Gewichtsbestimmung der Fadenwürmer (Nematoden). Acta Zool Hung 2: $1-15$

Atilla N, Wetzel MA, Fleeger JW (2003) Abundance and colonization of artificial hard substrate-associated meiofauna. J Exp Mar Biol Ecol 287:273-287

Boxshall GA, Halsey SH (2004) An introduction to copepod diversity. The Ray Society, Dorset Press, Dorchester

Bray JR, Curtis JT (1975) An ordination of the upland forest communities of Southern Wisconsin. Ecol Monogr 27: 325-349

Childress JJ, Fisher CR (1992) The biology of hydrothermal vent animals: physiology, biochemistry and autotrophic symbiosis. Oceanogr Mar Biol Annu Rev 30:337-441

Clarke KR, Gorley RN (2001) PRIMER v5: user manual/tutorial. PRIMER-E, Plymouth

Colaço A, Dehairs F, Desbruyères D (2002) Nutritional relations of deep-sea hydrothermal fields at the Mid-Atlantic Ridge: a stable isotope approach. Deep-Sea Res I 49: 395-412

Danovaro R, Fraschetti S (2002) Meiofaunal vertical zonation on hard-bottoms: comparison with soft-bottom meiofauna. Mar Ecol Prog Ser 230:159-169

Desbruyères D, Segonzac M, Bright M (eds) (2006) Handbook of hydrothermal vent fauna. Denisia, Linz

Dinet A, Grassle F, Tunnicliffe V (1988) Premières observations sur la meiofauna des sites hydrothermaux de la dorsale East-Pacifique (Guaymas, $21^{\circ} \mathrm{N}$ ) et de $1^{\prime}$ Explorer Ridge. Oceanol Acta 85:7-14

Fabiano M, Danovaro R (1999) Meiofauna distribution and mesoscale variability in two sites of the Ross Sea (Antarctica) with contrasting food supply. Polar Biol 22:115-123

Feller RJ, Warwick RM (1988) Energetics. In: Higgins RP, Thiel $\mathrm{H}$ (eds) Introduction to the study of meiofauna. Smithsonian Institution Press, Washington, DC, p 181-196

Giere O (1993) Meiobenthology, the microscopic fauna in aquatic sediments. Springer-Verlag, Berlin

Gollner S, Zekely J, VanDover CL, Govenar B, LeBris N, Nemeschkal H, Bright M (2006) Benthic copepod communities associated with tubeworm and mussel aggregations on the East Pacific Rise. Cah Biol Mar 47:397-402

Govenar B, LeBris N, Gollner S, Glanville J, Aperghis A, Hourdez S, Fisher CR (2005) Epifaunal community structure associated with Riftia pachyptila aggregations in chemically different hydrothermal vent habitas. Mar Ecol Prog Ser 305:67-77

Haymon RM, Fornari DJ, Edwards MH, Carbotte S, Wright D, Macdonald KC (1991) Hydrothermal vent distribution along the East Pacific Rise crest $\left(9.09-54^{\circ} \mathrm{N}\right)$ and its relationship to magmatic and tectonic processes on fast- 
spreading mid-ocean ridges. Earth Planet Sci Lett 104: 513-534

Heptner MV, Ivanenko VN (2002) Copepoda (Crustacea) of hydrothermal ecosystems of the World Ocean. Arthropoda Selecta 11:117-134

Higgins PR, Thiel H (1988) Introduction to the study of meiofauna, Smithsonian Insitution Press, Washington, DC

Humes AG (1987) Copepods from deep-sea hydrothermal vents. Bull Mar Sci 41:645-788

Ivanenko VN, Defaye D (2006) Copepoda. In: Desbruyères D, Segonzac M, Bright M (eds) Handbook of hydrothermal vent fauna. Denisia, Linz, p 316-355

Le Bris N, Govenar B, Le Gall C, Fisher CR (2006) Variability of physico-chemical conditions in $9^{\circ} 50^{\prime} \mathrm{N}$ EPR diffuse flow vent habitats. Mar Chem 98:167-182

Levesque C, Juniper SK (2002) Particulate matter as a food source at a nascent hydrothermal vent on the Juan de Fuca Ridge. Cah Biol Mar 43:289-292

Levesque C, Limén H, Juniper SK (2005) Origin, composition and nutritional quality of particulate matter at deep-sea hydrothermal vents on Axial Volcano, NE Pacific. Mar Ecol Prog Ser 289:43-52

McIntyre AD, Warwick RM (1984) Meiofauna techniques. In: Holme NA, McIntyre AD (eds) Methods for the study of marine meiobenthos, 2nd edn. Blackwell Scientific Publications, Oxford, p 217-244

Micheli F, Peterson CH, Mullineaux LS, Fisher CR, Mills SW, Sancho G, Johnson GA, Lenihan HS (2002) Predation structures communities at deep-sea hydrothermal vents. Ecol Mongr 72:365-382

Mullineaux LS, Peterson CH, Micheli F, Mills SW (2003) Successional mechanism varies along a gradient in hydrothermal fluid flux at deep-sea vents. Ecol Mongr 73: 523-542

Murray JW (1973) Distribution and ecology of living benthic foraminiferids. Heinemann, London

Nemeschkal HL (1999) Morphometric correlation patterns of adult birds (Fringillidae: Passeriformes and Columbiformes) mirror the expression of developmental control genes. Evolution 53:899-918

Ólafsson E (2003) Do macrofauna structure meiofauna assemblages in marine soft-bottoms? A review of experimental studies. Vie Milieu 53:249-265

Ólafsson E, Moore CG (1990) Control of meiobenthic abundance by macroepifauna in a subtidal muddy habitat. Mar Ecol Prog Ser 65:241-249

Olu K, Lance S, Sibuet M, Henry P, Fiala-Médioni A, Dinet A (1997) Cold seep communities as indicators of fluid expulsion patterns through mud volcanos seaward of the Barbados accretionary prism. Deep-Sea Res 44:811-841

Palmer MA, Montagna PA, Spies RB, Hardin D (1988) Meiofauna dispersal near natural petroleum seeps in the Santa

Editorial responsibility: Otto Kinne (Editor-in-Chief), Oldendorf/Luhe, Germany
Barbara Channel: a recolonization experiment. Oil Chem Pollut 4:179-189

Sarrazin J, Juniper SK, Massoth G, Legendre P (1999) Physical and chemical factors influencing species distributions on hydrothermal sulfide edificies of the Juan de Fuca Ridge, northeast Pacific. Mar Ecol Prog Ser 190:89-112

Sarrazin J, Levesque C, Juniper SK, Tivey MK (2002) Mosaic community dynamics on Juan de Fuca Ridge sulphide edifices: substratum, temperature and implications for trophic structure. Cah Biol Mar 43:275-279

Shank TM, Fornari DJ, Von Damm KL, Haymon RM, Lutz RA (1998) Temporal and spatial patterns of biological community development at nascent deep-sea hydrothermal vents ( $9^{\circ} 50^{\prime}$ N, East Pacific Rise). Deep-Sea Res II 45:465-515

Shirayama Y (1992) Studies of meiofauna collected from Iheya Ridge during the dive 541 of the 'SHINKAI 2000'. Proc JAMSTEC Symp Deep Sea Res 1992:287-290 (in Japanese, with English Abstract and Tables)

Soltwedel T (2000) Metazoan meiobenthos along continental margins: a review. Prog Oceanogr 46:59-84

Tsurumi M, Tunnicliffe V (2003) Tubeworm-associated communities at hydrothermal vents on the Juan de Fuca Ridge, northeast Pacific. Deep-Sea Res I 50:611-629

Tsurumi M, de Graaf RC, Tunnicliffe V (2003) Distributional and biological aspects of copepods at hydrothermal vents on the Juan de Fuca Ridge, north-east Pacific Ocean. J Mar Biol Assoc UK 83:469-477

Tunnicliffe V (1991) The biology of hydrothermal vents: ecology and evolution. Oceanogr Mar Biol Annu Rev 29:319-407

Van Dover CL, German CR, Speer KG, Parson LM, Vrijenhoek RC (2002) Evolution and biogeography of deep-sea vent and seep invertebrates. Science 295:1253-1257

Vanreusel A, Van den Bossche I, Thiermann F (1997) Freeliving marine nematodes from hydrothermal sediments: similarities with communities from diverse reduced habitats. Mar Ecol Prog Ser 157:207-219

Visman B (1991) Sulfide tolerance: physiological mechanisms and ecological implications. Ophelia 34:1-27

Warwick RM, Platt HW, Somerfield PJ (1998) Free-living marine nematodes, Part III, Monhysterids. The Dorset Press, Dorchester

Wieser W (1953) Die Beziehung zwischen Mundhoehlengestalt, Ernaehrungsweise und Vorkommen bei frei lebenden marinen Nematoden. Ark Zool 26:439-484

Zekely J, VanDover CL, Nemeschkal HL, Bright M (2006a) Hydrothermal vent meiobenthos associated with mussel (Bathymodiolus spp.) aggregations from Mid-Atlantic Ridge and the East Pacific Rise. Deep-Sea Res I 53:1363-1378

Zekely J, Sørensen VM, Bright M (2006b) Three new nematode species (Monhysteridae) from deep-sea hydrothermal vents. Meiofauna Mar 15:25-42

Submitted: April 19, 2006; Accepted: September 20, 2006

Proofs received from author(s): April 20, 2007 